PATRICIA E. PERKINS

\title{
BUILDING COMMONS GOVERNANCE FOR A GREENER ECONOMY
}

Much recent work in ecological economics and political ecology, including calls for "de-growth" in the transition towards more sustainable economies, focuses on commons as a promising paradigm for sustainable governance institutions. The vision involves people who depend on or have an interest in a resource or asset, working together co-operatively to use that asset for production, service provision, and exchange which creates value and well-being while integrating ecological care, justice, and long-term planning to the best of diverse communities' abilities. This includes institutions such as co-ops, land trusts, and non-market or beyond-market collective ways of organizing production, distribution, consumption, and waste or materials management.

Developing such collective institutions requires nurturing the skills and abilities needed to create and maintain them: empathy, communication and listening skills, a sense of shared purpose, creativity, dispute resolution across differences, long-term vision, environmental awareness and stewardship, among others. Transformative education praxis and transdisciplinarity facilitate the growth of these skills and abilities in children and adults, as Paulo Freire and other transformative learning practitioners have shown (Gadotti 2009; O'Sullivan 1999; Gutierrez \& Prado 1998). Transformative pedagogy, including both eco-pedagogy and transdisciplinarity, is foundational as human society evolves institutions for sustainability such as commons.

Commons are seen as better and more sustainable than private property and markets for a whole range of reasons: Markets can create strong incentives to over-exploit resources, exclude some users whose needs must then be met in other ways, generate pollution, ignore ecosystem services and long-term impacts, and otherwise "externalize" crucially-important costs of resource use while undercutting society's ability to address those costs and manage human development sustainably. Commons, on the other hand, allocate assets while also incorporating governance systems to limit overexploitation of resources and negative production impacts. Building effective forms of commons governance combines political economy, psychology, community development, gender/equity awareness, education, global and local policy, and ecological care with economics in ways that span and integrate many traditional disciplines and areas of human endeavour. In a time of global climate change, this interdisciplinary challenge takes on a grave imperative. 
Preventing the "tragedy" of commons, by controlling open access and exhaustion of resources for private profit through strong social, political and economic institutions, requires a high level of general civic consciousness, cooperation, the ability to listen and mediate differing goals, conflict resolution, flexibility, trust, and goodwill throughout society, especially in the context of social dynamism and diversity. As Elinor Ostrom said in her 2009 Nobel Economics Prize acceptance speech, "a core goal of public policy should be to facilitate the development of institutions that bring out the best in humans. We need to ask how diverse polycentric institutions help or hinder the innovativeness, learning, adapting, trustworthiness, levels of cooperation of participants, and the achievement of more effective, equitable, and sustainable outcomes at multiple scales." Ostrom and others have demonstrated through meticulous research that this does not always happen, but it is possible.

Paulo Freire's concept of participatory communal work is an expression of the spirit behind commons. In Pedagogy of the City, Freire stated, "Participation, or cooperation, for example through the so-called mutirões (state-community improvement initiatives where the community provides the manpower), used to repair school buildings and child-care facilities, to clean streets and parks. Without denying the importance of this kind of cooperation, for us participation should go further. For us participation involves a more active presence of the subordinate classes in history, instead of their mere representation. It involves the political participation of the popular classes, through their representations, on the decision-making level, not just to carry out pre-planned projects. The authoritarian understanding of participation obviously reduces it to a presence of the popular classes in the administration conceded only at certain moments. .... Popular participation, for us, is not a slogan, but the expression of the city's accomplishment of democracy and the way to it. The more firmly we consolidate the democratic practice of participation, the further away we will be moving, on the one hand, from antidemocratic, elitist practices and, on the other, from the no less antidemocratic grass-roots practices. I realize it is not easy to implement projects or experience community and grassroots participation as a government program and as a political ideal. Above all, it is not easy on account of authoritarian traditions, which we need to overcome." (Freire, 1993, p. 70).

This chapter summarizes and illustrates definitions and typologies of commons, citing some Canadian examples and theoretical contributions, and suggests some ways that education, policy and grassroots change may foster their (re)growth. It also outlines some ways that those working in policy, activism, and academia can foster commons growth and regrowth.

Aboriginal traditions of hospitality, sharing, potlatch (or giving away material wealth as a sign of moral and community standing), humility, and reverence for the earth and its creatures and life systems are good examples of locally appropriate 
commons governance processes. Many First Nations also had hierarchically nested governance systems that, in my view, correspond with what Elinor Ostrom has cited as successful ways to govern large-scale commons.

The interdisciplinary International Association for the Study of the Commons was formed in 1989, building on the Common Property Network, formed in 1984. IASC now has over 1,000 institutional members and has sponsored 12 international conferences, with the most recent in Japan in June 2013 and another planned for May 2015 in Alberta. There are regional meetings, an online digest, a digital library and bibliographies, and discussion groups (www.iasc-commons.org). New books on commons appear frequently now, and the idea that commons governance represents something fundamentally different from "the Market" or "the State" is becoming well known and widely accepted.

\section{DEFINITIONS AND TYPOLOGIES OF COMMONS}

So what exactly is a commons? The word is a somewhat odd collective noun, pluralized but singular - how do we understand and use this idea? There is a risk, noted already in the literature, that "commons" will become the latest glom-on term, co-opted and vague, obscuring more than it conveys. However, 'commons' starts out more overtly oppositional to capitalism than other terms like 'sustainability' or 'development', focusing as it does on ownership and property, land, resources, and assets that are explicitly NOT privately owned.

Commons take a big step towards internalizing externalities - to use neoclassical terminology - and towards discourse-based valuation of ecological and social goods and services, bringing politics together with economics, in the best alternative or heterodox traditions of political ecology and feminist ecological economics.

Ideas on common goods and their governance have a long history. The Justinian Code of CE 534 divided things into "res privatae, res publicae, res communes, res nullius, and res sacra. Res comunes included earth, water, air, sky, flora and fauna and navigable waterways" (Ricoveri, 2013, p. 37. In Europe and elsewhere, common land was long maintained for agricultural use, including hunting, foraging, and pasturing animals (Thompson, 1993). Worker and housing co-operatives, guilds, community barn-raisings, "mutual aid", and repeated examples worldwide of crises bringing out altruism, solidarity, generosity and courage in stricken communities are indications that people's desire to act communally is ever-present (Cato, 1993, pp. 9-12; Ricoveri, 2013, p. 63).

A recent book on commons and ecological governance says, "the commons is a term that applies to the resources utilized, owned or shared by multiple individuals on a group basis," (Suga, 2013, p. 4) “.... The traditional commons had to do with 
the management of resources on a local, not global, level. Those resources were not comprehensible if removed from the micro-societal context in which they existed.... (C)urrent-day, widespread use has diluted the formerly rigorous definition of the term 'commons,' ... and fostered a vast expansion in the scope of those resources now considered worthy of research within a commons-related context" (Ibid., 6). The book's editors state, "This volume rests on the perspective that modern society is composed of three elements: a public sector, common sector and private sector.... If humanity were a society driven by the profit motive alone, it would be a society of disparities highlighted by unbearable levels of inequality. That is why society demands the existence of a public sector committed to the redistribution or balancing of income and assets through the power of taxation.... Modern societies also incorporate a common sector that is neither public nor private... that operates independently of the profit motive or the interest in upholding public authority. Structures or communities of this nature are typically composed of households, various co-operatives or non-profit organizations.... (and) international volunteer associations.... Cooperation and/or coordination are the driving principles on which these organizations operate" (Murota \& Takeshita 2013, p. xxii).

Charlotte Hess and Elinor Ostrom (2007), long-time commons researchers, define the term as follows: "Commons is a general term that refers to a resource shared by a group of people. In a commons, the resource can be small and serve a tiny group (the family refrigerator), it can be community-level (sidewalks, playgrounds, libraries, and so on), or it can extend to international and global levels (deep seas, the atmosphere, the Internet, and scientific knowledge). The commons can be well founded (a community park or library); trans-boundary (the Danube River, migrating wildlife, the Internet); or without clear boundaries (knowledge, the ozone layer)" (Hess \& Ostrom, 2007, pp. 4-5).

In a recent book on commons, David Bollier and Burns H. Weston use the following definition: "A commons is a regime for managing common-pool resources that eschews individual property rights and State control. It relies instead on common property arrangements that tend to be self-organized and enforced in complex, idiosyncratic ways" (Weston \& Bollier, 2013, p. 125).

Italian commons activist Giovanna Ricoveri's definition is: "The commons are goods or means of subsistence which are not commodities, and therefore they constitute a social arrangement that is the complete opposite of the one created by the market economy" (Ricoveri, 2013, p. 31)... "The commons are local systems that can be managed effectively only by those who have a precise and detailed knowledge of the area and who know its history, language, culture, vegetation, mountains and other physical attributes" (Ibid., p. 34).... "Thus there does not exist, nor can there exist, a general law that is valid for all systems of the commons for the very reason - contrary to what is generally believed - that they are open local systems, receptive and adaptable to the local 'whims' such as climate, the different 
attributes of the localities in terms of natural resources, the knowledge of the inhabitants, their professionalism - all elements that cannot be defined in law" (Ibid., p. 36).

Elinor Ostrom too has emphasized the importance of locally constructed governance processes, local monitoring and enforcement of environmental quality and access to the resource. This makes monitoring more efficient, cost-effective, and accurate (Ostrom, 2012, p. 83).

To add some detail and ground these definitions, let's now examine several Canadian and international examples of commons. Following a bit of history to set the context, the next section discusses these examples at increasing scales from local to global.

\section{EXAMPLES OF COMMONS}

\section{Co-operatives and Credit Unions}

There is a long history in Canada of communities developing creative ways of securing social livelihood and building community resilience through cooperation. Canada still has the highest per-capita credit union membership in the world: $35 \%$ of Canadians are credit union members. According to the Canadian Co-operative Association (2013), there are approximately 9,000 co-operatives and credit unions in Canada which provide products and services to 18 million members in all economic sectors - agriculture, retail, financial services, housing, child care, renewable energy, etc. Co-ops have more than $\$ 370$ billion in member-owned assets, employ 150,000 people, and have strong links with their local communities via volunteerism, community donations and sponsorships. Their survival rate is higher than that of traditional businesses $(62 \%$ are still operating after 5 years, compared with $35 \%$ for traditional businesses; after 10 years the figures are $44 \%$ and $20 \%$ respectively.)

In Canada, mutual insurance companies were founded in the 1840s; dairy producer co-operatives in central and Atlantic Canada in the mid-1800s; the first known consumer co-operative in Stellarton, Nova Scotia, in 1864; a co-operative bank at Rustico, Prince Edward Island, also in 1864; and worker co-operatives connected with the Knights of Labour in the 1880s. According to University of Victoria emeritus history professor Ian MacPherson, historian of the Canadian cooperative movement, "For co-operators, the conviction that the 'common man' could reform the world..... found such easy acceptance in large part because so many Canadians had been exposed to the same notions in either the labour or the agrarian movements... In fact, when viewed internationally,... co-operation seemed to be the technique that would develop man" (MacPherson, 2007, p. 1820). And education was a necessary part of co-operative development, 
MacPherson points out. "To reform the world through the common man.... there was an imperative need for extensive education programs.... [T] he education programs were all based on the belief that the ordinary man, when exposed to the truth, would act and act wisely in the best interests of society (MacPherson, 2009, p. 20).

More recently, MacPherson states, "During the last two decades there has been a steadily widening and deepening interest in the development of different kinds of co-ops. Perhaps the most common area of interest has been in co-ops that provide 'slow food', food produced locally as much as possible, preferably organic, so as to lessen dependence on food produced elsewhere and brought to Canada in ways that seriously impact the environment. Across the country, too, there is a significant rise in transportation co-ops (e.g., car share co-ops, bike co-ops) and energy co-ops based on wind power or the production of biodiesel fuels. Many young people have found it useful to develop worker co-ops in the high tech industries or to seek alternative forms of housing. Communities facing health issues because of declining support of governments and aging populations have organized different kinds of health or service co-ops. These co-ops are similar to the new co-ops found around the world, a modern rebirth..." (MacPherson, 2009, pp. 18-19).

\section{Local Commons in Toronto, Ontario}

Here are a few examples of organizations and projects in my home city that are building local commons. Similar examples exist in most Canadian communities, and in local areas around the world.

Not Far From The Tree (which was started by Laura Reinsborough in 2008) puts Toronto-grown fruit to good use by picking and sharing it locally. Fruit trees planted long ago in the city are still producing lots of apples, pears, cherries, berries, and other fruit. According to the organization's website, "When a homeowner can't keep up with the abundant harvest produced by their tree, they let us know and we mobilize our volunteers to pick the bounty. The harvest is split three ways: $1 / 3$ is offered to the tree owner, $1 / 3$ is shared among the volunteers, and $1 / 3$ is delivered by bicycle to be donated to food banks, shelters, and community kitchens in the neighbourhood so that we're putting this existing source of fresh fruit to good use. It's a win-win-win situation! This simple act has profound impact. With an incredible crew of volunteers, we're making good use of healthy food, addressing climate change with hands-on community action, and building community by sharing the urban abundance" (Not Far from the Tree website, 2013).

The Yes in My Backyard program similarly links volunteers and landowners to grow vegetables in Toronto. "Many people would like to garden but live in 
apartment buildings or do not have access to yard space suitable for growing food. And yet others have access to a yard but do not have the time, interest, or the physical ability to maintain a vegetable garden. Some just like the idea of cooperating with others to create a garden together. Whatever the motivation for participating, YIMBY is working to build community and strengthen relationships between people who might not have otherwise met" (Yes in My Backyard website, 2013).

Located on eight acres of city-owned conservation flood plain land in North Toronto, and coordinated by an award-winning food and agriculture education and advocacy organization, the Black Creek Community Farm helps build community food security and food justice by producing healthy vegetables which are sold locally through harvest shares, farmer's markets, and volunteer programs. Its mission is "to engage, educate and empower diverse communities through the growing and sharing of food" (Black Creek Community Farm website, 2013).

Community-supported agriculture farms (CSAs) exist across Canada and in many other countries around the world. Food consumers purchase a share of each year's mixed vegetable crop at the beginning of the growing season, providing cash up-front for farmers and spreading the risks and rewards of agriculture. In some CSAs, consumers also help out in the fields. An Ontario website provides a directory of CSA farms across the province so that potential customers can find one in their area (Community Supported Agriculture website, 2013).

Also in Toronto, the Anarres Worker Co-operative, formed in 2003, provides affordable technology services and online communications tools for the non-profit social sector, including website development, hosting, and IT support. Their website says, "We ... believe computer technology and the web should primarily be tools for community building. We are passionate about using open source software for reasons of both utility and ethics. We believe in its affordability, flexibility and effectiveness.... We are activists and social advocates in our own right, and we strive to bring this aspect of ourselves to our work as much as we do our technical competence and experience" (Anarres, 2013).

The Co-operative Housing Federation of Toronto represents more than 45,000 people living in more than 160 non-profit housing co-operatives. Since 1975 it has provided development assistance for new housing co-ops, as well as education and services, a bulk-buying program for its members, information for the public in eight languages, diversity education, and policy support (Co-operative Housing Federation, 2013).

\section{Regional and International Commons}


The Bruce Trail extends 885 kilometres from Queenston, near Niagara Falls, to Tobermory, on Lake Huron in central Ontario. It was built and is maintained by nine regional clubs of the Bruce Trail Conservancy, which maintain a conservation corridor and public footpath along the Niagara Escarpment - a UNESCO World Biosphere Reserve - through the "kind permission" of private landowners, coordination with public lands and roadways, and the gradual purchase of land through a charitable preservation fund (Shimada, 2010). The regional clubs also organize volunteer-led nature walks, hikes and excursions, including a series of hikes where participants meet at Toronto subway stations and go by bus to the hike site.

The Great Lakes Commons Initiative, begun in 2010, is "a cross-border grassroots effort to establish the Great Lakes as a commons and legally protected bioregion" (Great Lakes Commons, 2013). One of its projects is the participatory development of an online map of the Great Lakes linking stories and crowdsourced information, creating a shared space for dialogue and exploration (Great Lakes Commons Map, 2013). The Great Lakes Commons Initiative is a collaborative, incubated project of On the Commons, a commons movement strategy centre founded in 2001 which publishes a magazine and online newsletter, and hosts a resource centre and network of commons "animateurs" (On the Commons, 2013).

The non-profit Marine Conservation Institute brings together scientists, local conservation groups and activists, and governments to advocate for trans-boundary protection of oceans, and is working with government officials, activists and conservation organizations to publicize and begin organizing a "Baja to Bering" ocean conservation corridor, including important offshore biological diversity conservation sites from Alaska and British Columbia to southern California in the eastern Pacific (Marine Conservation Institute, 2013).

\section{Global Commons}

The Sky Trust is a proposal to establish a governance structure to control and charge polluters for their atmospheric emissions. Proceeds would accrue to the Trust, which would use them for clean energy investments or dividends. "Sky Trust ... would encourage less pollution because it would reward the commons owners - all of us - for tough emission limits.... For decades we have been told that there are only two choices for the management of scarce resources: corporate self-seeking or the bureaucracy of the state. But there is another way. Commons management has worked for centuries and is still working today. It can be adapted to the most pressing global problems, such as climate change. A new phrase is about to enter the policy realm. To 'market-based' and 'command-and-control' we can now add 'commons-based"” (Rowe, 2008, paragraphs 64-77). 
Creative Commons is a non-profit organization based in Massachusetts that helps to distribute and manage shared creativity and knowledge. Says their website, "The idea of universal access to research, education, and culture is made possible by the Internet, but our legal and social systems don't always allow that idea to be realized. Copyright was created long before the emergence of the Internet, and can make it hard to legally perform actions we take for granted on the network: copy, paste, edit source, and post to the Web. The default setting of copyright law requires all of these actions to have explicit permission, granted in advance, whether you're an artist, teacher, scientist, librarian, policymaker, or just a regular user. To achieve the vision of universal access, someone needed to provide a free, public, and standardized infrastructure that creates a balance between the reality of the Internet and the reality of copyright laws. That someone is Creative Commons" (Creative Commons, 2013).

These very brief examples indicate, at different scales, how commons can be assembled, managed, enjoyed and governed by groups of people using a combination of NGO, government, and private structures, rules, and incentives. Each is different; each has its own constituency and provides distinct services or generates value for its members or "commoners". When considered broadly, these benefits extend beyond the commoners to others in society, which is partly what motivates the commons' development and existence, and also shows why commons fill important gaps in state or private/market forms of governance.

The next section explores some ideas, partly drawn from these examples, regarding the skills and social education needed to help commons initiatives grow and flourish.

\section{EDUCATION AND SKILLS NEEDED FOR COMMONS}

Elinor Ostrom's research has demonstrated that successful commons governance institutions share several characteristics:

- They face uncertain and complex environments

- The local population is stable over long periods of time; people care about their reputations and expect their descendants to inherit the land

- Norms have evolved which allow individuals to live in close interdependence with each other and the community is not severely divided

- The resource systems and institutions have persisted over time; they are robust and sustainable.

Ostrom (1990) developed a set of "design principles" that help to account for the success of those commons governance institutions that have proven to work well:

1) Clearly defined boundaries for the commons 
AUTHOR NAMES

2) Congruence between appropriation and provision rules and local conditions (local appropriateness)

3) Collective-choice arrangements (individuals can participate in modifying the rules)

4) Monitoring of the rules by members takes place

5) There are graduated sanctions for violations of rules

6) Rapid, low-cost conflict-resolution mechanisms exist

7) Rights to organize are recognized, at least minimally (outside authorities do not challenge the rights of members to devise their own institutions) and, for larger systems

8) There are multiple layers of nested enterprises which perform governance functions (Ostrom, 1990, pp. 89-90).

Tiered and nested organizational layers exist in many co-operative federations and credit unions, as Quarter, Armstrong, \& Mook (2009) note in their study of the social economy in Canada. "The tiering arrangement represents a type of functional integration in which co-operatives with common needs co-operate with each other through an apex organization that helps them with their service provision. Often apex organizations serve as the voice of the sector (its members) to government, seeking to represent their needs. Sometimes they provide practical services to member organizations such as assistance with loans, loan guarantees, and information... (or as) brokers for national and international markets... (and) business associations" (p. 67). This shows how commons management is qualitatively different from both state/government organization and market rationality.

Quarter et. al. also discuss the growth in Canada of multi-stakeholder cooperatives or "solidarity co-operatives" which involve workers, consumers, and other community organizations in co-op governance. In 1990 the Co-operators Group insurance company proposed to the Ontario government that it would create a non-profit auto insurer with three sets of members, each with defined rights: drivers, employees, and government representatives. The proposal was not accepted, but it led to new initiatives in Quebec and internationally. By 2004 there were 121 multi-stakeholder co-ops in Quebec, most providing homecare to seniors and others in need. "Having a worker co-operative as part of a broader organization - as in a multi-stakeholder or a worker-shareholder co-operative reduces the financial load for employees and the inordinate risk of a worker cooperative" (Quarter et al. 2009, p. 66). Some social economy businesses combine for-profit and non-profit arms, link businesses with membership organizations, include government agencies as partners, supplement paid services with volunteers, or combine commercial and charitable services (Quarter et. al., 2009, pp. 71-74).

What are the attributes and skills required in the general populace for commons to be managed well, and for this paradigm and framework to spread? It should be obvious by now that we are not talking about a wholesale, sudden substitution of 
commons-type goods and service provision for everything supplied by the market; rather this is a slow progression where commons of various kinds gradually expand in the interstices and meet the many gaps in the global and local economy, whenever (and exactly because) commons meet some needs better than any other system. It's possible to envision a nearly infinite overlapping set of communications and governance structures covering all kinds of commons and groups of people, from watersheds, air-sheds, agricultural areas, and political jurisdictions to epistemic commons, information commons, groups of music lovers (such as the "beehive" of Beyoncé fans or the "little monsters" who listen to Lady Gaga), "Out of the Cold" shelter networks, community-shared agriculture and food box groups, arts and culture groups of all kinds, and all the networks which create social, political, ecological and economic communities. This addresses social and psychological needs for belonging which may be as important as material needs in keeping a socio-economy running well, and is a topic that is related to the question of how to reduce material throughput while maintaining health and well-being.

Thus, interesting ideas about skills generation and transmission for commons come from a range of fields including Community Development, Systems Theory, Whole Psychology, Philosophy, Eco-feminism, and many other fields (Hyde, 2010; Mellor, 2012; Bond, 2009; Bakker, 2007; The Ecologist, 1992).

Ken Conca, in writing on how to nurture improved institutions for global water governance, states, "Scholarship on the effective sustained management of common-property resources has shown the importance of institutions as secondorder public goods that help to provide the underprovided good of social cooperation. One obvious area in which such second-order public goods would facilitate the nurturing of institutions is resolution of environmental disputes... The dispute-resolution approach could also be linked to growing interest in the idea of environmental peacemaking... processes such as co-operative knowledge ventures and the emergence of regional-scale identities might help to transform situations of conflict and insecurity using environmental relationships as catalysts, with nonstate channels as important venues" (Conca, 2006, pp. 384-385.

Weston and Bollier speak of innovations in law and policy being needed in three areas, to foster commons governance: (a) general internal governance principles and policies for commons, building on the work of Elinor Ostrom and the Indiana University Workshop in Political Theory and Policy Analysis where she carried out much of her research; (b) macro-principles and policies that the State/Market can embrace to develop commons and "peer governance"; and (c) catalytic legal strategies to validate, protect and support commons (Bollier \& Weston, 2012, p. 349). As examples, they cite conceptualizing commons as equal and legitimate partners with the state and the private sector - a triad of State/Market/Commons for governance options; adapting private contract and property law to protect commons, as in the GPL or General Property License which copyright owners can attach to software to assure that the code and any 
future modifications to it will be forever accessible for anyone to use; the Global Innovation Commons, a huge international database of lapsed patents; "stakeholder trusts" to manage and lease ecological resources on behalf of common groups and distribute revenues to them, such as the Alaska Permanent Fund or a Sky Trust; relocalization and "transition towns" movements; Community Supported Agriculture and Slow Food movements assisted by government policies; expansion of the public trust doctrine of environmental law to include atmosphere and water; wikis and crowd-sourced platforms to include citizen experts in policy-making and enforcement, participatory environmental monitoring of water quality and biodiversity, etc. (Weston \& Bollier, 2013, p. 351).

Computer technologies, online organizing and communications now allow people to create participatory global, regional, and epistemic communities and commons of many new kinds. According to legal scholar Beth S. Noveck, these forms of collective action are potentially vibrant and efficient, and should be recognized and encouraged in law by allowing legitimate, decentralized selfgovernance (Noveck, 2005).

\section{CONCLUSION}

"Big History" scholar David Christian has identified a key human characteristic which has made it possible for our species to dominate earth's ecosystems: our ability to communicate and share knowledge over space and time, which he calls "collective learning" (Christian, n.d.). Addressing the challenges we humans have created, especially global climate change, will require us to use this collaborative facility more successfully than ever before. Besides naming, describing, and prioritizing transformative educational praxis, we will need to seek creative ways of establishing and fostering commons for democratic and engaged governance at all levels and stages of human endeavour.

In Paulo Freire's words, "In truth, one of our political tasks that we need to assume is to make viable the dreams that appear impossible. In other words, we need to diminish the distance between the dream and its realization... (T)he transformation of the world is an educational task in itself. We know that education cannot accomplish all, but it can achieve some things... It behooves us to put the power of education at the service of our dreams" (Freire, 1993, p. 123).

Democracy doesn't start from the presupposition that we are all equal, but that we are different. When we want to transform this multiplicity of interests into one collective interest guided by human rights, social movements and parties are fundamental... By means of communication, we represent and imagine the 
desirable, that is, we construct the imaginary, we make and represent the things that we want from the world and from ourselves..... One of the characteristics of poverty is symbolic exclusion from communication systems. The Third Sector should, therefore, succeed in making minorities' or poor people's ways of seeing, feeling, working and expressing themselves an equal part of the symbolic universe which circulates in society.

-Jose Bernardo Toro, A construção do público: cidadania, democracia e participação, pp. 55-60. (Translated by the author.)

\section{REFERENCES}

Anarres Worker Co-operative (2013). http://anarres.ca/ Accessed 17 July 2014.

Bakker, Karen (2007). "The 'commons' versus the 'commodity': alter-globalization, anti-privatization and the human right to water in the Global South." Antipode, vol. 39 no. 3, pp. 430-455.

Black Creek Community Farm. (2013). http://everdale.org/blackcreek/. See also: http://www.cbc.ca/news/canada/toronto/urban-farm-near-jane-and-finch-to-receive-400-000-grant$\underline{1.2074258 ;}$

http://www.thestar.com/news/gta/2013/10/16/janefinch farm rakes in first harvest.html Accessed 17 July 2014.

Bollier, D, \& Helfich, S. (Eds.). (2012). The wealth of the commons: A world beyond market and state. Amherst, MA: The Commons Strategies Group / Levellers Press.

Bond, Patrick (2010). “South Africa's 'rights culture' of water consumption: Breaking out of the liberal box and into the commons?" Available online: http://ccs.ukzn.ac.za/files/Bond\%20culture $\% 20$ of $\% 20$ water $\% 20$ rights $\% 20$ final.pdf . Accessed 17 July 2014.

Canadian Co-operative Association. (2013). "Co-op facts and figures," CCA website, http://coopscanada.coop/en/international dev/about/facts. Accessed 17 July 2014. See also: http://www.planetfriendly.net/coop.html;

http:/www.coopscanada.coop/assets/firefly/files/files/Ethnocultural co-ops report final.pdf. Accessed 17 July 2014.

Cato, M. S. (2004). “The Earth is our Mother - What are the economic implications?” Available online: http://www.gaianeconomics.org/pdf/ecofem.pdf. Accessed 17 July 2014.

Christian, D. (n.d.). Big history project. https://www.bighistoryproject.com/thresholds/6 . Accessed 17 July 2014.

Community Supported Agriculture. (2013). $\underline{\text { http://csafarms.ca/. }}$ See also: http://www.davidsuzuki.org/what-you-can-do/queen-of-green/faqs/food/what-are-communitysupported-agriculture-farms/?gclid=CND3mIaO6rsCFdE-Mgodp04Amw. Accessed 17 July 2014.

Conca, Ken (2006). Governing water: contentious transnational politics and global institution building. Cambridge: MIT Press. 


\section{AUTHOR NAMES}

Co-operative Housing Federation of Toronto. (2013). http://www.coophousing.com/. Accessed 17 July 2014

Creative Commons. (2013). http://creativecommons.org/about._Accessed 17 July 2014.

The Ecologist (1992). Special issue: Whose Common Future? Vol. 22, no. 4, July/August.

Freire, P. (1993). Pedagogy of the city. New York: Continuum.

Gadotti, Moacir (2009). Education for Sustainability: a contribution to the Decade of Education for Sustainable Development. São Paulo, Brazil: Editora e Livraria Instituto Paulo Freire. Available online:

http://acervo.paulofreire.org:8080/xmlui/bitstream/handle/7891/3081/FPF PTPF 12 078.pdf.

Accessed 29 September 2014.

Great Lakes Commons. (2013). http://www.greatlakescommons.org/. Accessed 17 July 2014.

Great Lakes Commons Map. (2013). http://greatlakescommonsmap.org/main. Accessed 17 July 2014.

Gutierrez, Francisco \& Cruz Prado (1998). Ecopedagogia e Cidadania Planetaria. São Paulo, Brazil:

Cortez.

Hess, C. \& Ostrom, E. (2007). Understanding knowledge as commons: From theory to practice. Cambridge, MA: MIT Press.

Hyde, Lewis (2010). Common as Air: Revolution, Art and Ownership (New York: Farrar, Straus \& Giroux).

Marine Conservation Institute. (2013). http://www.marine-conservation.org/what-we-do/programareas/mpas/baja2bering/\#sthash.0erSPrqb.dpuf. Accessed 17 July 2014.

MacPherson, Ian (2007). One Path to Co-operative Studies. Victoria, BC: British Columbia Institute for Co-operative Studies / New Rochdale Press. Available online: http://www.uvic.ca/research/centres/cccbe/assets/docs/publications/RochdalePress/OnePath to Coo perativeStudies.pdf Accessed 29 September, 2014. Accessed 29 September 2014.

MacPherson, I. (2009). The history of the Canadian co-operative movement: A summary, a little historiography, and some issues." Available online: http://socialeconomyhub.ca/content/telelearning-session-19-long-view-social-economy. Accessed 17 July 2014

Mellor, Mary (2012). "Cooperative principles for a Green Economy." Capitalism Nature Socialism, vol. 23, iss. 2, pp. 108-110. Available online: http://www.tandfonline.com/doi/abs/10.1080/10455752.2012.675237? journalCode=rens20\#.U8g9jI $\underline{1 \mathrm{dVOQ}}$. Accessed 17 July 2014.

Murota, T. \& Takeshita, K. (2013). Local commons and democratic environmental governance. Tokyo/New York/ Paris: United Nations University Press.

Not Far from the Tree. (2013). http://www.notfarfromthetree.org/about/what-we-do. Accessed 17 July 2014.

Noveck, B. S. (2005, November). A democracy of groups. First Monday, 10(11) 11, xx-xx[NOTE: page numbers required]. Available at: http://firstmonday.org/ojs/index.php/fm/article/view/1289/1209. Accessed 17 July 2014.

On the Commons. (published monthly). http://onthecommons.org/. Accessed 17 July 2014. 
Ostrom, E. (1990). Governing the commons: The evolution of institutions for collective action. New York: Cambridge University Press.

Ostrom, E. (2009). Beyond markets and states: polycentric governance of complex economic systems. Nobel Economics Prize lecture, December 8, 2009. Available online: http://www.nobelprize.org/nobel prizes/economic-sciences/laureates/2009/ostrom lecture.pdf Accessed 17 July 2014.

Ostrom, E. (2012). The future of the commons: Beyond market failure and government regulation. London: Institute of Economic Affairs.

O'Sullivan, Edmund (1999). Transformative Learning: Educational vision for the $21^{\text {st }}$ century. Toronto: University of Toronto Press.

Quarter, J., Armstrong, A., \& Mook, L. (Eds.). (2009). Understanding the social economy: A Canadian perspective. Toronto: University of Toronto Press.

Ricoveri, G. (2013). Nature for sale: The commons versus commodities. London: Pluto Press.

Rowe, J. (2008). The parallel economy of the commons. State of the World Report 2008. Available online: http://jonathanrowe.org/the-parallel-economy-of-the-commons Accessed 17 July 2014.

Shimada, D. (2010). How can societies create common access to nature? The roots and development process of the Bruce Trail, a Canadian case study. Post-doctoral research paper, York University, Faculty of Environmental Studies. Available online: http://dlc.dlib.indiana.edu/dlc/bitstream/handle/10535/7369/356.pdf?sequence=1. Accessed 17 July 2014.

Suga, Y. (2013). The tragedy of the conceptual expansion of the commons. In T. Murota \& K. Takeshita (Eds.), Local commons and democratic environmental governance (pp. 3-18). Tokyo/New York/Paris: United Nations University Press.

Thompson, E. P. (1993). Customs in common. New York: The New Press.

Toro, J. B. (2005). A construção do público: cidadania, democracia e participação. Rio de Janeiro: SENAC.

Weston, Burns H. \& David Bollier (2013) Green Governance: Ecological survival, human rights, and the law of the commons. Cambridge: Cambridge University Press.

Yes in My Back Yard. (2013). http://thestop.org/yes-in-my-back-yard. Accessed 17 July 2014. 